On returning to the heronry (Sec. 10 T34 R16 W2), I was excited to discover the egrets nesting among the herons. The egrets were occupying two nests among the 19 active heron nests. Both egrets and herons appeared to be incubating. Pieces of broken eggshell were found lying at the base of the trees indicating that young were present. The calls of the young were also audible. As no young were observed, I was unable to determine whether there were egret young present. The egret nests were situated about 25-30 feet high in aspen poplar (Populus tremuloides). The egrets reacted aggressively to any approach by the larger herons. When a heron landed on a tree occupied by an egret nest, the egrets chased it off. During my short observation period, the herons did not appear to be aggressive to the egrets and tolerated them at close range.
I took a few photos of the birds at their nests but to prevent any further disturbance I did not climb up to check the contents. I was unable to return to the colony during the summer to check on nesting success. This also was the first time the heronry had been recorded for the province.

The only previous nesting record of the Common Egret was reported by $\mathrm{E}$. L. Fox who, in September, 1955, confirmed the nesting site of this species in the Qu'Appelle Valley approximately 7 miles east of Craven.

There have been other reported sightings of the Common Egret for Saskatchewan but this is only the second breeding record.

'FOX. E. L. 1955. Great American Egret. Blue Jay 13(4): 7.

\title{
OSPREY - BALD EAGLE RELATIONSHIPS IN SASKATCHEWAN
}

JONATHAN M. GERRARD, 954 - 15th Ave. S.E., Minneapolis, Minn. 55414;

DOUGLAS W. A. WHITFIELD, Department of Botany, University of Alberta, Edmonton, Alberta. T6G 2E9;

WILLI AM J. MAHER, Department of Biology, University of Saskatchewan, Saskatoon, Saskatchewan. S7N OW0

While reviewing Osprey nesting in northern Saskatchewan, one of us (JMG) suggested that Ospreys tend to be more tolerant of human disturbance than Bald Eagles, and may gradually partially replace eagles as roads are pushed farther into the forested areas of Saskatchewan. To test this hypothesis, we plotted all Osprey and Bald Eagle nests found on our aerial surveys of the boreal forests of central Saskatchewan and determined their relationship to roads. The study area is shown in Figure 1 and has been described in detail previously. ${ }^{17}$
We feel that our method allows a reasonable comparison between the two species in different regions, despite the fact that the Osprey nests were found on surveys for Bald Eagle nests, that eagles may be more conspicuous, and that a higher percentage of eagle than Osprey nests may be found along the shoreline routes. Each survey unit is a block of 30 minutes latitude measuring roughly 35 miles in a north-south direction and nearly 40 miles east-west. There are also three smaller survey units along the eastern Saskatchewan boundary. For each sur- 
Fig. 1. The relative distribution of successful Bald Eagle (BE) and Osprey (O) nests in parts of north-central Saskatchewan covered by aerial surveys in 1969 and 1971. The number of miles of shoreline searched (SS) and the presence of a road (R) in each survey unit is shown.

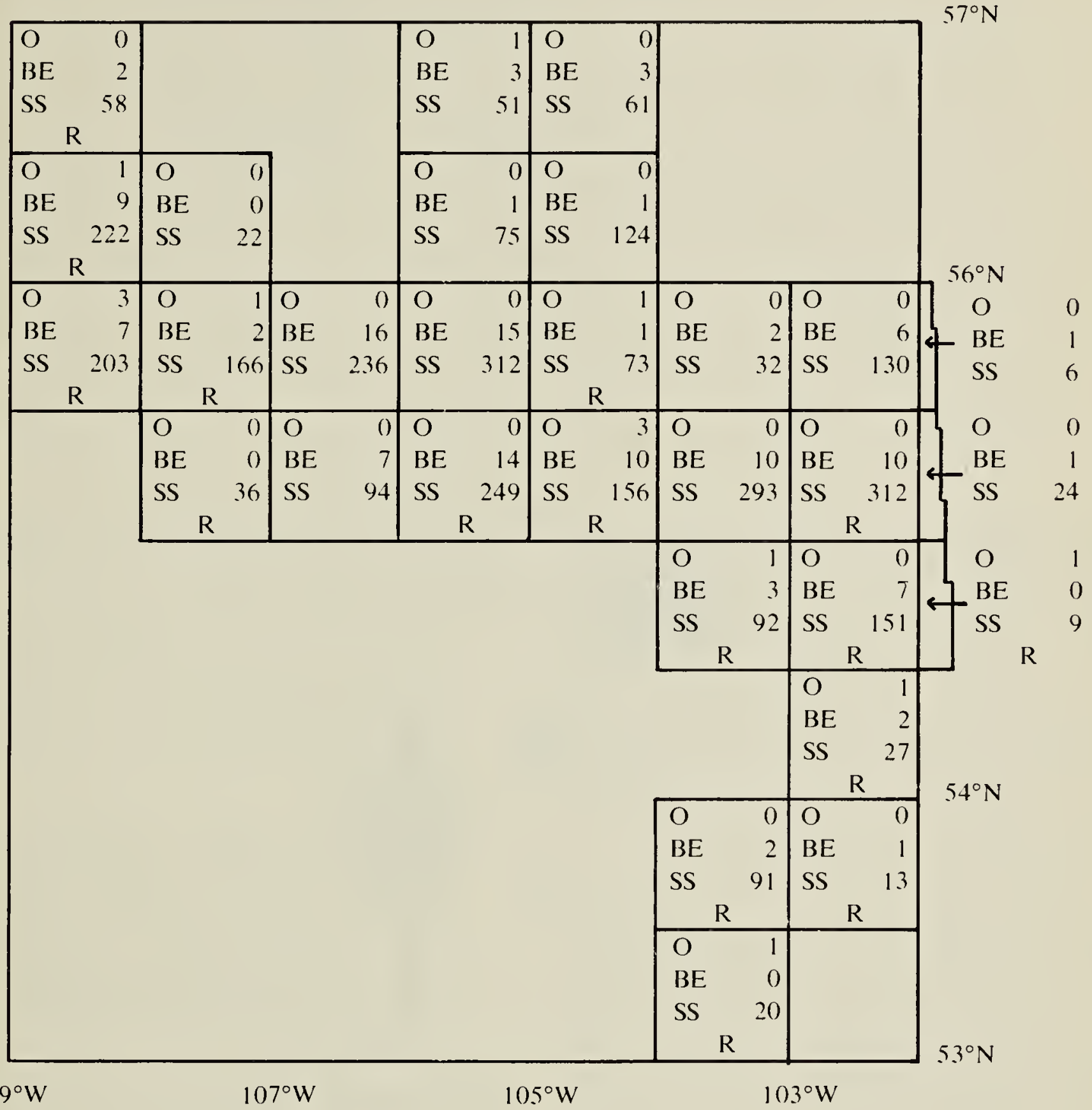

vey unit, the graph (Figure 1) shows the number of active Osprey and Bald Eagle nests, miles of shoreline searched and the presence or absence of a road at the time of the survey.

In 10 of 16 survey areas with roads, we found 13 pairs of nesting Ospreys while searching 1,878 miles of shoreline. In contrast, we found only one pair of Ospreys along 1,462 miles of shoreline in 13 survey units with no roads. ${ }^{*}$ In areas with roads, the ratio of Osprey to Bald Eagle nests was 13:70 (1:5.4), while in areas without roads the ratio was 1:66. The Loon Lake area, long interlaced with roads, has a reversed ratio of 15 active Osprey nests and no Bald Eagle nests, as reported by Scott and Surkan. ${ }^{14}$ For the areas we surveyed, the increase in numbers of nesting Osprey is associated with a concomitant decrease in numbers of nesting Bald Eagles (Table 1). Attempts to relate the relative distribution of eagles and Ospreys to other geographic features including whether nests were north or south of the Precambrian Shield revealed no significant differences.

Our finding that Ospreys nest more frequently in areas where there is greater human influence than in more 
Table I: The Relative density of successful Bald Eagle and Osprey nests in survey areas with and without roads.

The number of successful breeding areas found per 1000 miles of shoreline searched

Survey areas with roads

Bald Eagles

Ospreys

Total
37.3

\section{Survey areas}

without roads

45.1

0.7

45.8 remote areas is in accord with the pattern of Osprey and Bald Eagle associations seen in northwestern Ontario. Around Lake of the Woods, where there is considerable human activity, there are approximately equal numbers of Bald Eagles and Ospreys ${ }^{6}$ ${ }^{9}$, whereas north of Lake of the Woods where there are few roads relatively few Ospreys have been found. ${ }^{\prime}$

While the Ontario data and our Saskatchewan surveys support the thesis that Osprey nesting is related to human incursions, our Saskatchewan data suggest that additional factors are probably involved." Ospreys have nested at two lakes, Cree Lake and Reindeer Lake, north beyond our survey routes. These large northern lakes are somewhat marginal habitat for Bald Eagles since they remain covered with ice for long after the eagles on the Churchill River have begun nesting. Ospreys, however, return to the northland closer to the time of breakup with its availability of fish (Figure 2).

\footnotetext{
*This difference is highly significant, with less than a one percent possibility that it could have occurred by chance $\left(\mathrm{x}^{2}=7.8, \mathrm{DF}=1, \mathrm{p}<0.01\right)$. If the data were analyzed using onl; those Osprey and Bald Eagle nests which we found for the first time, and omitting any nests which we had learnt about previously from others, the difference in Osprey nesting between survey units with roads and those without roads is still highly significant.
}

We can thus revise our original hypothesis as follows:

1. In areas of high quality Bald Eagle nesting habitat, where human disturbance is minimal, nesting Ospreys are relatively rare as determined by our survey methods.

2. In areas where there is considerable human influence including roads, survey towers, power lines, and dams, Ospreys may be relatively common. Ospreys may also be present in areas of marginal Bald Eagle nesting habitat.

DISCussION: There is considerable overlap in the food and habitat requirements of Bald Eagles and Ospreys. Both species prey on live and dead fish, ${ }^{2}{ }^{7}$ with an overlap in the fish species taken in Florida. "

Shoreline nest site requirements also overlap, with both species tending to nest close to the shores of lakes and rivers. Mathisen has pointed out that Bald Eagles nest in the more protected crotch of a large tree, whereas Ospreys nest in the more exposed tree top. ${ }^{10}$. In northern Saskatchewan, similarity in the nest sites of these two raptors is greater. Thus while Ospreys in both Saskatchewan and Minnesota nest only on the exposed tops of trees, rocks or man-made structures, and Bald Eagles 


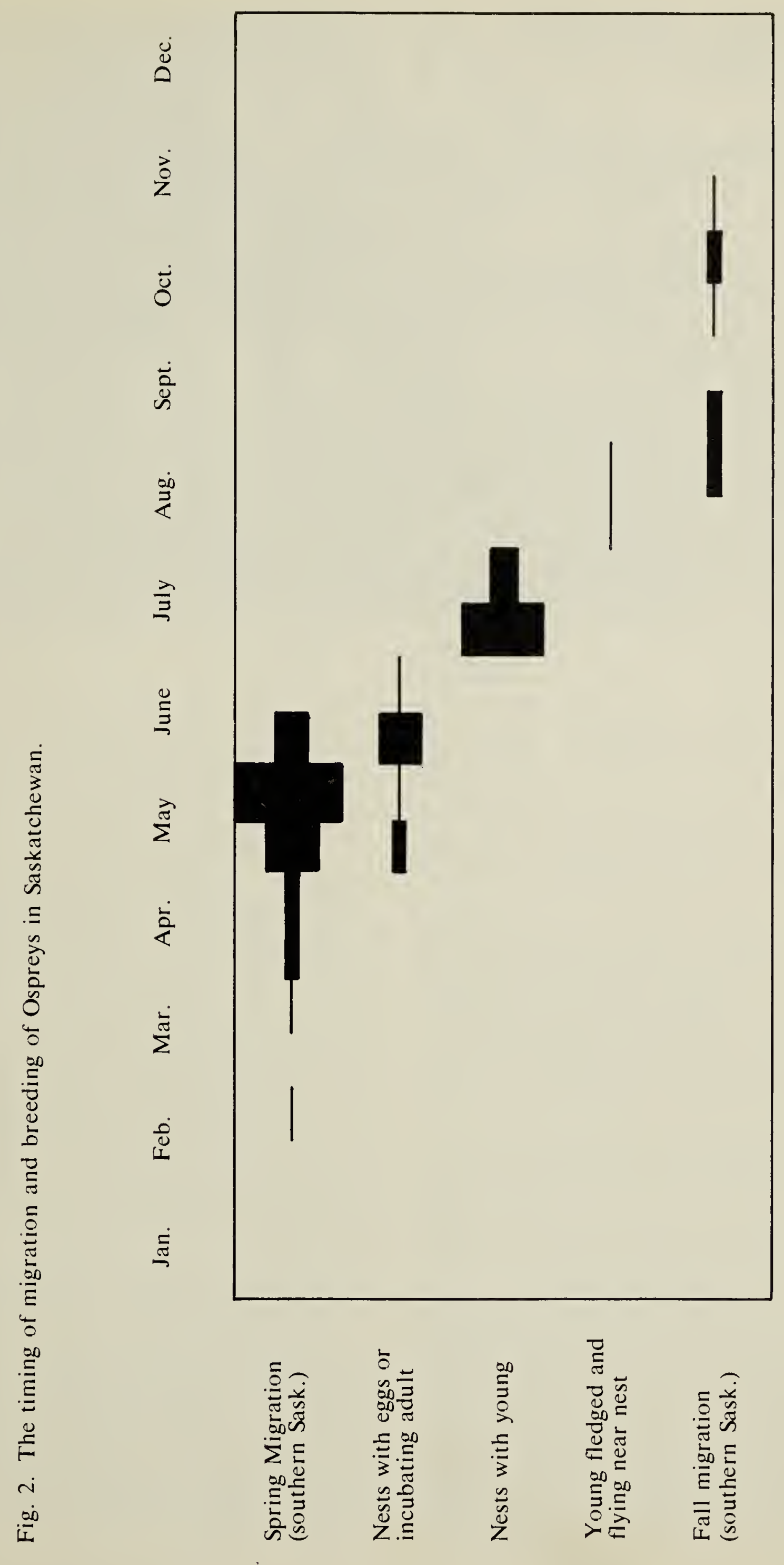

December, 1976. 34(4) 
are usually well below the top, it is also true that Saskatchewan Bald Eagles commonly nest on exposed tree tops.

In view of the overlap in the ecological niches of Osprey and Bald Eagles as we currently understand them, the lack of Ospreys in undisturbed areas where there is high quality Bald Eagle nesting habitat needs an explanation. A ratio of one Osprey to 66 successful Bald Eagle nests in such undisturbed high quality Bald Eagle habitat suggests that eagle dominance in such habitat in Saskatchewan is virtually complete. One possibility is that the degree of interspecies competition between the two species is greater than has hitherto been suspected and Ospreys are driven out of areas where eagles prefer to nest. Ogden has demonstrated clearly that such territorial competition between the two species can occur, and that eagles moving into an area can displace Ospreys and result in decreased Osprey nesting success. ${ }^{12}$ In Saskatchevan neither raptor is a year round resident and the arrival of the Bald Eagle about a month ahead of the Osprey could certainly give it the advantage in the selection of prime territory and nest sites.

The result of such dominance would be that Ospreys are forced to nest in poor to marginal Bald Eagle habitat where they might have specific advantages. The following classification of Osprey nesting areas supports this viewpoint:

1. Areas with considerable human disturbance. Bald Eagles are very susceptible to human disturbance at the nest ${ }^{1}{ }^{4}$ whereas Ospreys are relatively less susceptible (Rob Hernandez pers. comm.).

2. Areas with man-made structures for nest sites. We have not found Bald Eagles nesting on man-made structures in Saskatchewan and such nesting is rare elsewhere. In contrast, Ospreys readily nest on geodesic survey towers, on power poles along the line from Flin Flon to Sherridon, Manitoba, ${ }^{1 ;}$

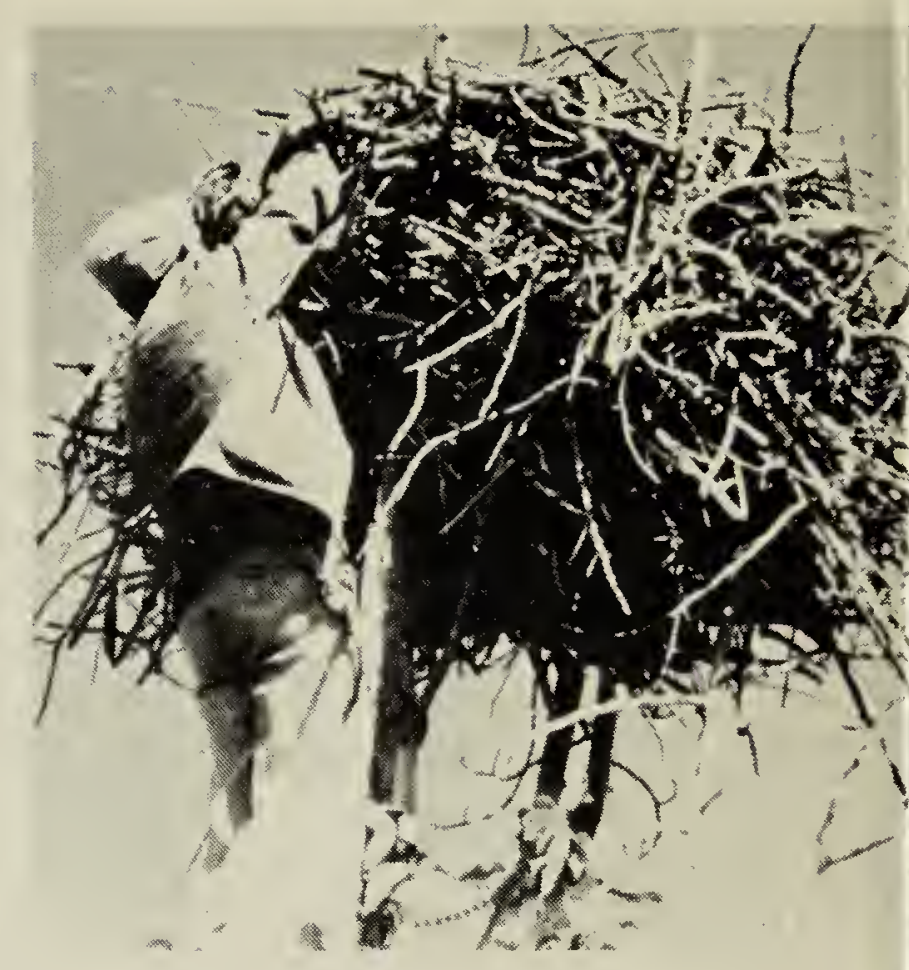

Stuart Houston at Osprey nest.

Frank Scott

and on man-made platforms in Michigan. ${ }^{1: 3}$

3. Areas with late thaws. Large bodies of water in northern Saskatchewan, such as Cree and Reindeer Lakes, are frozen for some time after Bald Eagles have begun nesting, and have no open water at rapids or where small streams enter the lake for eagles to fish early in spring. 'S Smaller lakes north of our study area, including Irvine, Lavigne and Swan Lakes may also fit into this category. Swenson, :n Yellowstone National Park, also found that "Bald Eagle territories were limited by open water at the time of nest initiation", whereas "the presence of ice did not affect the placement of Osprey nests because they generally nested at the time of ice-out." $1 . \overline{ }$

4. Areas flooded by dams. The relative absence of Bald Eagles immediately upstream, certainly for the first fifteen miles above the Island Falls and Squaw Rapids dams in Saskatchewan has not been explained. Ospreys however, nest in these areas, and Ospreys are similarly common ir floodings in Michigan anc Wisconsin. ${ }^{13}$ 


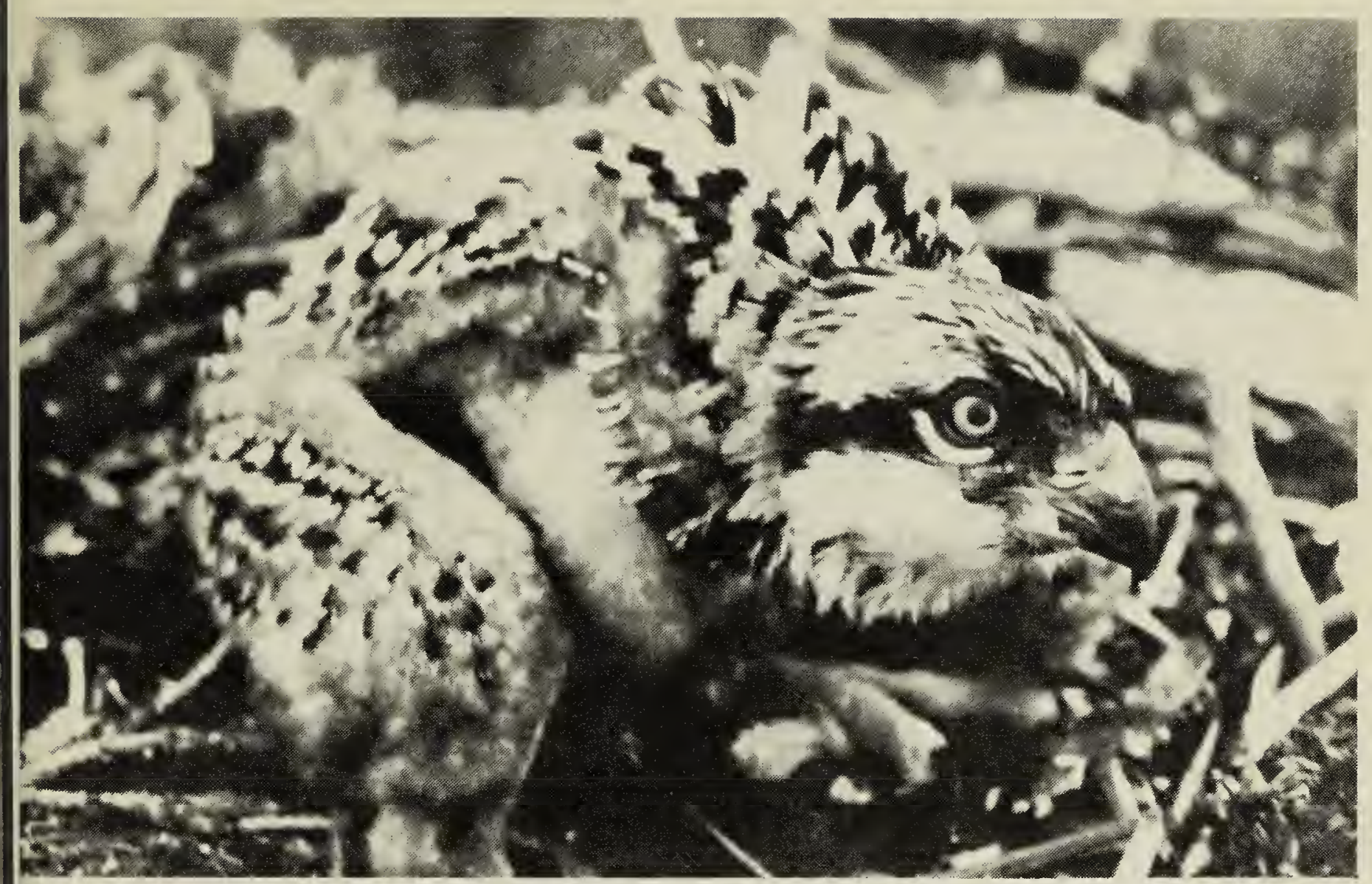

Young Osprey in nest.

Stuart Houston

As an alternative to the above theory of a high degree of interspecific competition with the Bald Eagle dominant, we might consider whether the food or nest site requirements of the two species is sufficiently different to account for their relative distribution in northern Saskatchewan. Postupalsky mentions a requirement for clear shallow water for Osprey fishing, ${ }^{13}$ while Swenson notes that Ospreys at Yellowstone Lake foraged mostly in deep water. ${ }^{14}$ Both authors agree, however, that Ospreys take fish fonly from the top few inches of the lake. Bald Eagles do the same. Furthermore we can think of no obvious water quality differences between Lac La Ronge, Churchill, Peter Pond, Amisk, and Upper Foster Lakes where here are Ospreys, and Besnard, Pinehouse, and Black Bear Island Lakes where we have found none.

It may well be that Bald Eagles take nore dead fish and that Ospreys prefer ive fish, though we know that both ake some of each. Such a preference vould give eagles an advantage on akes fished commercially, though Herrick states that many, if not most, of the fish caught by Bald Eagles during the breeding season may be alive. ${ }^{7}$

Bald Eagles are larger than Ospreys and may take larger fish. In a lightly fished area, where the fish tend to be larger, the Bald Eagle might have an advantage. In a heavily fished area, usually associated with a road, average fish size decreases and could confer an advantage to the Osprey.

Bald Eagles tend to fish more from shoreline perches or from glide pathways on updrafts along shoreline, while Ospreys spend relatively more time in flapping and hovering flight at a greater distance from shore. Ospreys might thus have an advantage on larger lakes.

The tendency of Ospreys to nest on man-made structures suggests that nest sites might be limiting. However, since one-fifth to one-third of Saskatchewan Bald Eagle nests are on the exposed top of spruce or jack pine trees typical Osprey nest sites - this seems unlikely, unless one assumes interspecies competition. Finally, the small differences in nest site or fishing requirements discussed above, or as 


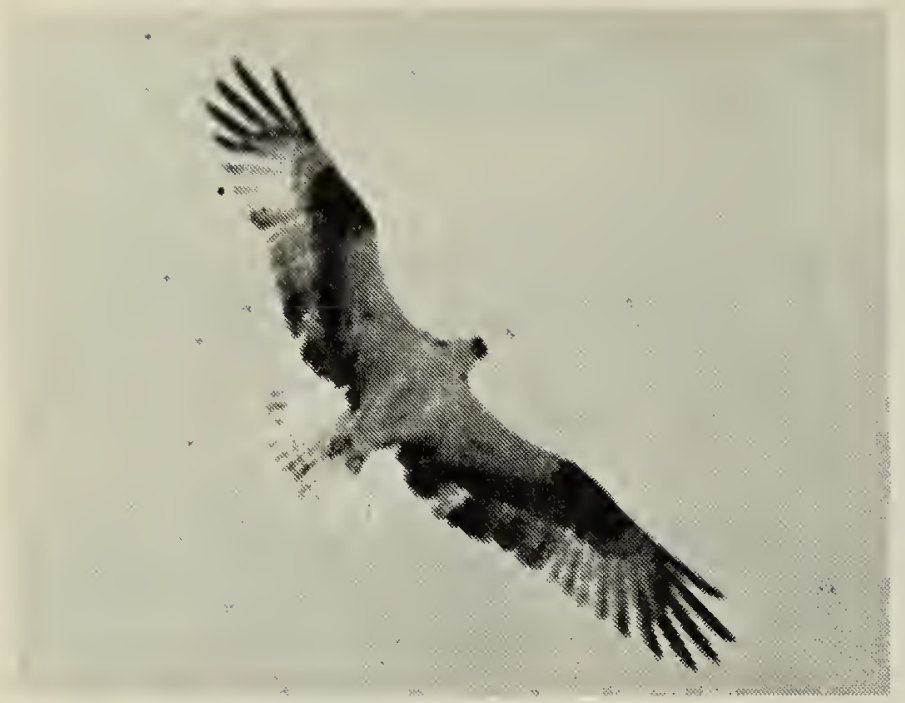

Osprey overhead

Frank Scott

yet unidentified habitat factors may play a more critical role than we presently appreciate.

We have thus far discussed two alternate hypotheses 1) interspecies competition and 2) availability of habitat and prey as possible explanations for the present distribution of Bald Eagle and Osprey nesting in northern Saskatchewan. The two hypotheses are not mutually exclusive and both may have contributed to the present situation. Our findings suggest that we may expect more Ospreys and fewer Bald Eagles as more roads and more people penetrate the prime Bald Eagle habitat of northern Saskatchewan, a suggestion that will be tested in the years to come. Of related interest are the increased sightings of Ospreys at Hawk Mountain, Pennsylvania in recent years, following the earlier decline in Bald Eagle sightings there. ${ }^{11}$ Our present study provides a possible explanation for such a phenomenon.

ACKNOWLEDGEMENTS: We wish to thank C. Stuart Houston for constructive criticism and suggestions. Our studies have been supported financially by the Canadian Wildlife Service, the Institute of Northern Studies at the University of Saskatchewan and by the National Research Council through its grant to W. J. Maher.

BUCKLE, D. J., J. M. GERRARD, P. GERRARD, W. J. MAHER, N. OBERHOLTZER, J. STILBORN and D. W. A. WHIT. FIELD. Bald Eagle Behaviour Study 1970. Part I. Unpublished report to the Canadian Wildlife Service.
'DUNSTAN, T. C. 1973. The Biology of Ospreys in Minnesota. The Loon 45: 108.

'GERRARD, C. D. and J. M. GERRARD. 1971 A Bald Eagle Survey in the Region Surrounding Buffalo Narrows, Saskatchewan 1971. Unpublished report to the Canadian Wildlife Ser vice.

${ }^{4}$ GERRARD, J. M., P. GERRARD. P. N GERRARD, D. W. A. WHITFIELD and W. J. MAHER. 1973. Buld Eagle hehaviour study Part II. Final report to the Canadian Wildlife Service on contract CWS-7273-43.93 p. (mimeo).

'GERRARD, J. M., P. GERRARD, W. J. MAHER and D. W. A. WHITFIELD. 1975. Factors Influencing Nest Site Selection of Bald Eagles in Northern Saskatchewan and Manitoba. Blue Jay 33: 169.

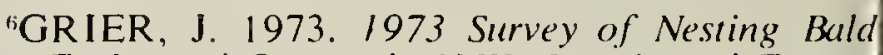
Eagles and Ospreys in N.W. Ontario and Eastern Manitoba. Unpublished report to the Canadian Wildlife Service.

${ }^{7}$ HERRICK, F. H. 1934. The American Eagle. New York. D. Appleton-Century Co., New York, N.Y., 267 p.

${ }^{8}$ HOUSTON, C. S., J. M. GERRARD, D. W. A. WHITFIELD, H. A. STELFOX and W. J. MAHER. 1976. Osprey Nesting Records in Saskatchewan. Blue Jay this issue.

"MANSELL, W. D. 1965. Eagle Nesting Survey of the Lake of the Woods Area. Canadian Audubon 27: 18-21

"MATHISEN, J. E. 1968. Identification of Bald Eagle and Osprey Nests in Minnesota. The Loon 40: $113-114$.

"NAGY, A. C. 1975. Hawk Mountain Osprey Project. Proceeding of the North American Hawk Migration Conference 1974. Shiver Mountain Press, Washington Depot, Connecticut, p. 147.

12OGDEN, J. C. 1975. Effects of Bald Eagle Territoriality on Nesting Ospreys. Wilson Bulletin 87: 496-505.

13POSTUPALSKY, S. and S. M. STACKPOLE. 1974. Artificial Nesting Platforms for Ospreys in Michigan in Management of Raptors. F. N. Hamerstrom Jr., B. E. Harrell and R. R. Olendorff Eds. Raptor Research Report No. 2. Vermillion S.D. 146 pp.

'SCOTT, F. and D. L. SURKAN. 1976. An Unsuspected Osprey concentration in West-Central Saskatchewan. Blue Jay 34: 98.

1.5WENSON, J. E. 1975. Ecology of the Bald Eagle and Osprey in Yellowstone National Park. MSc. Thesis. Montana State University, Bozeman.

16WHITFIELD, D. W. A., J. M. GERRARD and W. J. MAHER. 1969. Bald Eagle Survey in Central Saskatchewan and Manitoba 1969. Unpublished report to the Canadian Wildlife Service.

i'WHITFIELD, D. W. A., J. M. GERRARD, W J. MAHER and D. W. DAVIS. 1974. Bald Eagle Nesting Habitat, Density, and Reproduction in Central Saskatchewan and Manitoba. The Canadian Field Naturalist 88: 399-407. 


\section{INGVALD OPSETH WILDLIFE REFUGE}

One hundred and sixty acres of wood and marsh land in the Crystal Springs district were dedicated as the "Ingvald Opseth Wildlife Refuge" in a ceremony last Sunday afternoon. Tourism and Renewable Resources Minister John R. Kowalchuk and Odd Opseth, a brother of the late Ingvald Opseth, unveiled a cairn on Highway 20, 3 miles north of Crystal Springs to mark the 14th wildlife refuge in Saskatchewan. The quarter section of natural habitat is located at the north end of Dixon Lake, 12 miles southeast of Birch Hills...
"Mr. Opseth was truly concerned about wildlife," the Minister continued, "donating this land to ensure its protection". Kowalchuk pledged that the government would work to ensure the land serves the purpose for which he intended ... "Mr. Opseth's donation is a wonderful gesture, and I hope it will encourage others to follow suit. What could be a greater legacy than leaving a piece of the world, as we know it, to our sons and daughters and their sons and daughters?" the speaker asked ... - From Kinistino (Sask.) Post, September 17, 1975. Courtesy of Mike Vikanes.

\section{COUGARS IN THE QU'APPELLE VALLEY}

\section{TOM WHITE, 2256 McIntyre St., Regina, Sask. S4P 2R9}

The Qu'Appelle Valley stretches for approximately 200 miles in an eastwest direction from the South Saskatchewan River to the Assiniboine River just inside the Manitoba border. Cougar reports along its length have continued for the last 30 years and there are rumours of further sightings prior to that date.

The first report in some detail is that of Wilfred Rainville who came upon a cougar in a stubble field north of Sintaluta in 1942. Joe Brown tracked a cougar near Tyvan in the winter of 1946 and Frank Brazier observed a cougar cub in 1960 on Boggy Creek near Regina. There are concentrations of reports in the Vermilion Hills where the Qu'Appelle joins the south Saskatchewan and at Craven, Katepwa and Rocanville. It should be noted that reports occur where good local communications exist, but this does not necessarily indicate where most cougar sightings occur.

The cub sighting in 1960 is close to where a pregnant female was noted by a railway crew 10 years later and this might indicate a denning area. Craven is at an intersection of valleys in four directions and if a 20 -mile radius were taken from there, or any other point on the Qu'Appelle, it gives 1,000 square miles of creeks, coulees, trees and a substantial number of deer, the cougar's primary food. It is near this area that the latest reports have occurred.

George Polsom was driving to his ranch in the summer of 1975 when his headlights picked up an animal like a deer coming out of the ditch in front of his truck. He stamped on the brakes to avoid hitting it and realized that it was a cougar bounding across the road 